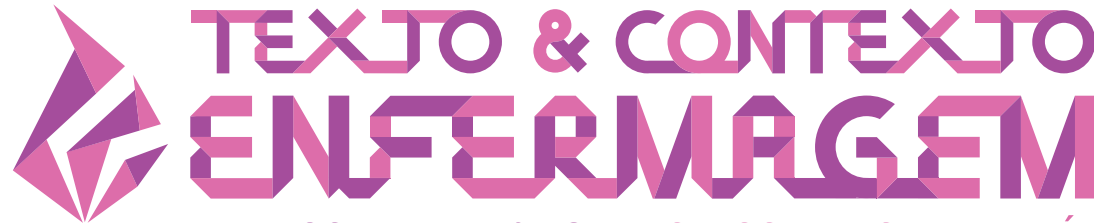

TEXT \& CONTEXT NURSING TEXTO \& CONTEXTO ENFERMERÍA

\section{NURSING INTERFACES IN RURAL CARE: AN INTEGRATIVE REVIEW}

\section{Ângela Roberta Alves Lima ${ }^{1,2}$ (1) José Siles González ${ }^{3}$ () Maria del Carmen Solano Ruiz ${ }^{3}$ (1) Rita Maria Heck ${ }^{2}$ (1)}

${ }^{1}$ Prefeitura Municipal de Pelotas. Pelotas, Rio Grande do Sul, Brasil. ${ }^{2}$ Universidade Federal de Pelotas. Pelotas, Rio Grande do Sul, Brasil. ${ }^{3}$ Universidad de Alicante. Alicante, Espanha.

\begin{abstract}
Objective: to know the issues in evidence in rural nursing.

Method: a six-stage integrative review. Data was collected from May to July 2017, in the SciELO, CUIDEN, PubMed, and ScienceDirect databases, with "Rural nursing" as descriptor. The analysis used was qualitative with the construction of subsets and topics.

Results: of the 30 articles analyzed, $32 \%$ addressed professional training; $25 \%$ collective health-related practices; $12 \%$ hospital care; $10 \%$ job satisfaction; $7 \%$ were dedicated to telehealth and $3 \%$ of the studies addressed the following topics: nurses' recruitment and permanence in rural areas, continuing education, and professional practice in urgency and emergency regulation centers.

Conclusion: working in rural areas demands that nurses face particularities such as isolation, difficulty of access, diverse socioeconomic conditions and specific epidemiological profiles, which influence the professional practice, making it a challenge.
\end{abstract}

DESCRIPTORS: Rural nursing. Health of the rural population. Public health. Nursing in community health. Nursing care. 


\section{INTERFACES DA ENFERMAGEM NO CUIDADO RURAL: REVISÃO INTEGRATIVA}

\section{RESUMO}

Objetivo: conhecer os temas em evidência na enfermagem no território rural.

Método: revisão integrativa composta por seis etapas. Os dados foram coletados no período de maio a julho de 2017, nas bases SciELO, CUIDEN, PubMed, ScienceDirect, com o descritor "Rural nursing". A análise utilizada foi qualitativa com a construção de subconjuntos e tópicos.

Resultados: dos 30 artigos analisados $32 \%$ abordavam a formação profissional; $25 \%$ ações relacionadas a saúde coletiva; $12 \%$ assistência hospitalar; $10 \%$ a satisfação no trabalho; $7 \%$ dedicaram a telessaúde e $3 \%$ dos estudos trataram dos temas: recrutamento e permanência das Enfermeiras no Espaço rural, educação permanente e a atuação profissional em central de regulação de urgência e emergência.

Conclusão: a atuação no território rural demanda à enfermeira enfrentar particularidades como isolamento, dificuldade de acesso, condições socioeconômicas diversas e perfis epidemiológicos específicos, que influenciam a prática profissional, o que a torna um desafio.

DESCRITORES: Enfermagem rural. Saúde da população rural. Saúde pública. Enfermagem em saúde comunitária. Cuidado de enfermagem.

\section{INTERFACES DE ENFERMERÍA EN LA ATENCIÓN RURAL: UNA REVISIÓN INTEGRADORA}

\section{RESUMEN}

Objetivo: conocer los temas en evidencia en la enfermería en el territorio rural.

Método: revisión integradora compuesta por seis etapas. Los datos se recolectaron de mayo a junio de 2017 en las bases de datos SciELO, CUIDEN, PubMed y ScienceDirect, con el siguiente descriptor: "Rural nursing". El análisis empleado fue el cualitativo con la elaboración de subconjuntos y temas.

Resultados: de los 30 artículos analizados, el 32\% abordaron la formación profesional; el 25\%, acciones relacionadas con la salud colectiva; el 12\%, la atención hospitalaria; el 10\%, la satisfacción en el trabajo; el $7 \%$ estaban dedicados a la telesalud y el $3 \%$ de los estudios trataron dos temas: reclutamiento y permanencia de las enfermeras en el Espacio rural, educación permanente y desempeño profesional en la central de regulación de urgencias y emergencias.

Conclusión: para desempeñarse profesionalmente en el territorio rural, una enfermera debe hacer frente a diversas particularidades como el aislamiento, la dificultad de acceso, condiciones socioeconómicas diversas y perfiles epidemiológicos específicos, que influyen sobre la práctica profesional, factores que la convierten en un desafío.

DESCRIPTORES: Enfermería rural. Salud de la población rural. Salud pública. Enfermería en salud comunitaria. Atención de enfermería. 


\section{INTRODUCTION}

Ensuring that people living in rural and remote areas have access to a sufficient number of qualified health workers at the right place and at the right time is one of today's most complex challenges. It is estimated that approximately half of the world's population lives in rural areas; however, only $38 \%$ of the nursing professionals work in these areas. ${ }^{1}$

Rural populations have cultural particularities and care histories that differentiate them from populations in other contexts. Appreciation of the land and contact with animals and plants stand out as part of a complex of values that comprehend living, production, social relations, and care. In this territory, work involves all family members and, in it, emotions, agreements, ethical conflicts, identity, diseases, resilience, and death are expressed..$^{2-3}$ Health assumes a broad perspective, interconnecting with the production of life process in an interface with the environment. ${ }^{4}$

These territories present several challenges to the health professionals, specifically to Nursing: geographical distance, difficulty in transportation and access to health resources, factors associated with the need to provide care to people who develop labor activities with a predominance of manual and unhealthy work. The work is carried out in adverse climatic conditions, with the use of chemical products, often harmful, such as pesticides and fertilizers. This interaction directly impacts on the health-disease process and the care system of these families.

Studies point out ${ }^{2-4}$ that the health services still cannot meet the specificities of the rural population. There is a need to carry out a professional practice aimed at the health of rural areas, which will help to promote and prevent diseases that affect this population. The care system is considered by farmers to be distant from their territory and belonging to the urban area, with few exchange interfaces and no dialog with family care practices. ${ }^{3}$

A review study conducted at the base of the Latin American and Caribbean Center on Health Sciences Information (Bireme) and on the Virtual Health Library (Biblioteca Virtual em Saúde, BSV) page, showed an increase in the scientific production on the rural population, with a predominance of epidemiological clinical studies, without, however, revealing aspects involving the nursing practice, identifying this gap. ${ }^{5}$ Given the above, this integrative review sought to know the issues in evidence in rural nursing.

\section{METHOD}

A six-stage integrative review was conducted. ${ }^{6}$ In the first stage the research question was identified: What are the themes developed by nursing in the national and international rural context? This question is based on the fact that nursing, as a practice that seeks to perform care encompassing popular and scientific knowledge, considering the cultural and regional aspects, develops different practices that enable to qualify care in the rural context. In the second stage the inclusion criteria were established: articles that (i) present practices developed by nursing in rural health services; (ii) deal with the qualification in rural nursing; (iii) address aspects related to continuing education developed for nurses in the rural context. The exclusion criteria used were the following: (i) review articles; (ii) publication previous to 2006; (iii) addressing activities of rural midwives; (iv) addressing health issues of the rural population; $(v)$ investigating the care or self-care developed by families and rural communities; (vi) nursing action developed for indigenous and aboriginal populations.

The search was conducted from May to July 2017, in the SciElo org, CUIDEN, PubMed, and ScienceDirect databases, with "Rural nursing" as descriptor, and in three languages: English in the PubMed and ScienceDirect databases, Portuguese in SciElo org, and Spanish in CUIDEN. The recommendations of the Preferred Reporting Items for Systematic reviews and Meta-Analyses 
(PRISMA) were used. The search took place in the advanced refinement mode and, in PubMed, MeshTerms and studies in human beings were searched for.

460 articles were found and distributed as follows: 58 in PubMed, 110 in SciElo, 67 in ScienceDirect e 225 in the CUIDEN database. After reading the titles and abstracts, the following were excluded: 42 review articles; 34 duplicates; 348 for not meeting the inclusion criteria; a total of 36 articles remaining in the study. After reading eight articles in their entirety, they were excluded from the sample because they addressed the indigenous population; software evaluation, because they did not bring themes developed by rural nursing; referencing services in the urban territory that serve the rural population; not addressing nursing; and because they were quantitative studies. And another two studies cited by the studies were included in the sample, totaling 30 articles (Figure 1).

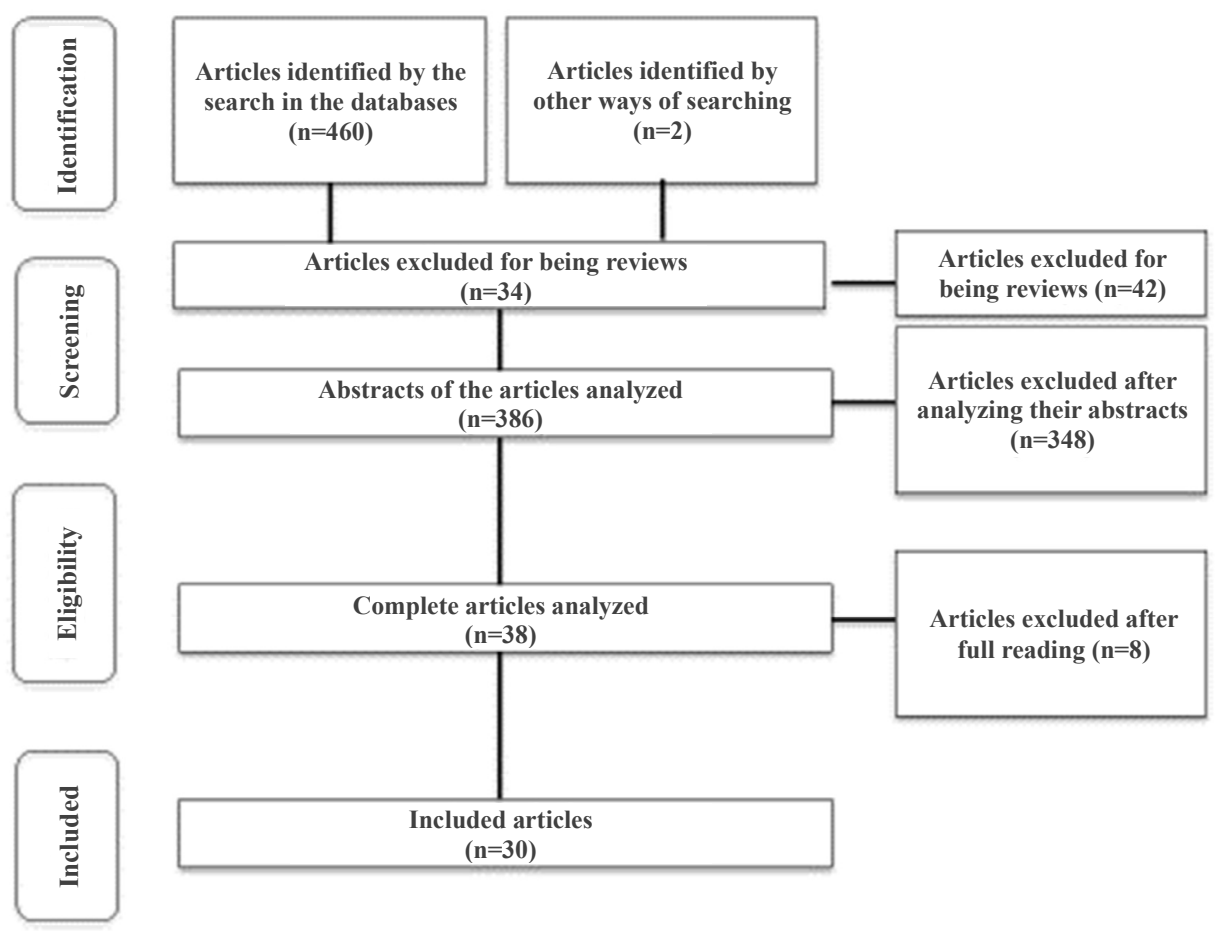

Figure 1 - Database and search strategy selected. Pelotas, RS, Brazil, 2018.

Then, the data were extracted electronically using a pre-constituted and standardized data form, containing the following: database, title, authors, year, institution, country, journal of publication, methodology, and results.

Subsequently, the qualitative analysis ${ }^{7}$ was initiated with the transversal elaboration of a set or subset of ideas present in the text. Initially, the data were organized by database in a table, with number, access, authors, reviewed institution, methodology, and main results. After reading the articles in their entirety, fragments of the text were extracted as presented in the results and final considerations of the articles, which were organized into subsets: collective health; recruitment, telehealth; training; hospital care; continuing education; central regulation and job satisfaction. These subsets constituted the first classification of the data.

Next, the data of each subset were read again in order to understand the structures of relevance presented, which gave rise to two topics, namely: Aspects that influence the practice of rural nursing; skills and challenges of rural nursing. The fifth stage consisted in the discussion and interpretation of the results obtained, followed by the sixth stage, with the presentation of the evidence found. 


\section{RESULTS}

It was identified that $80 \%$ were published after 2010, the year in which the World Health Organization (WHO) recommended expanding the supply and ensuring the permanence of health professionals in rural and remote areas.

Regarding the country of origin, $84 \%$ came from: Australia (40\%), USA (27\%) and Canada $(17 \%)$, countries that have a large territorial extension, with the first two standing out in agricultural production.

Among the studies, 32\% addressed professional training; $25 \%$ practices related to Public Health; $12 \%$ hospital care; $10 \%$ job satisfaction; $7 \%$ Telehealth and $3 \%$ addressed the following topics: nurses' recruitment and permanence in rural areas; continuing education and professional practice in emergency and urgent regulation centers (Chart 1).

Chart 1 - Synthesis of articles included in the integrative review. Pelotas, RS, Brazil, 2018.

\begin{tabular}{|c|c|c|}
\hline Authors & Country & Theme \\
\hline Knight K, Kenny A. ${ }^{8}$ & Australia & Regulation Central \\
\hline Bish M, Kenny A, Nay R. ${ }^{9}$ & Australia & Hospital care \\
\hline $\begin{array}{l}\text { Beckstrand RL, Rohwer J, Luthy KE, } \\
\text { Macintosh JLB, Rasmussen RJ. }{ }^{10}\end{array}$ & USA & Hospital care \\
\hline Kenny A, Allenby A ${ }^{1} 1$ & Australia & Hospital care \\
\hline $\begin{array}{l}\text { Beckstrand RL, Giles VC, Luthy KL, } \\
\text { Callister PLC, Heaston S. }{ }^{12}\end{array}$ & USA & Hospital care \\
\hline $\begin{array}{l}\text { Fairchild MR, Everly M, Bozarth L, Bauer R, } \\
\text { Walters L, Sample M, et al. }{ }^{13}\end{array}$ & USA & Permanent education \\
\hline Lea J, Cruickshank M. ${ }^{14}$ & Australia & Training \\
\hline $\begin{array}{l}\text { Hauenstein EJ, Glick DF, Kane C, Kulbok P, } \\
\text { Barbero E, Cox K. }{ }^{15}\end{array}$ & USA & Training \\
\hline Tschetter L, Lubeck P, Fahrenwald N${ }^{1} 6$ & USA & Training \\
\hline Pront L, Kelton M, Munt R, Hutton A. ${ }^{17}$ & Australia & Training \\
\hline $\begin{array}{l}\text { Yonge OJ, Myrick F, Ferguson LM, } \\
\text { Grundy Q. }{ }^{18}\end{array}$ & $\begin{array}{l}\text { Canada } \\
\text { USA }\end{array}$ & Training \\
\hline Sanderson H, Lea J. ${ }^{19}$ & Australia & Training \\
\hline $\begin{array}{l}\text { Place J, MacLeod M, John N, Adamack M, } \\
\text { Lindsey AE. }{ }^{20}\end{array}$ & Canada & Training \\
\hline Sedgwick MG, Yonge $0 .{ }^{21}$ & Canada & Training \\
\hline Mills J, Francis K, Bonner A.22 & Australia & Training \\
\hline Latham H, Giffard L, Pollard M. ${ }^{23}$ & Australia & Training \\
\hline Kulig JC, Kilpatrick K, Moffitt P, Zimmer L. ${ }^{24}$ & Canada & Recruitment \\
\hline Yates K, Kelly J, Lindsay D, Usher K. ${ }^{25}$ & Australia & Satisfaction \\
\hline Terri Bolin T, Peck D, Moore C, Ward-Smith P. ${ }^{26}$ & USA & Satisfaction \\
\hline Hoodless M, Bourke L.27 & Australia & Satisfaction \\
\hline Knight K, Kenny A, Endacott R. ${ }^{28}$ & Australia & Collective health \\
\hline MacKinnon K, Moffitt P. ${ }^{29}$ & Canada & Collective health \\
\hline $\begin{array}{l}\text { Moules NJ, MacLeod MLP, Thirsk LM, } \\
\text { Hanlon N. }{ }^{30}\end{array}$ & Canada & Collective health \\
\hline
\end{tabular}


Chart 1 - Cont.

\begin{tabular}{|c|c|c|}
\hline Authors & Country & Theme \\
\hline $\begin{array}{l}\text { Fraile MB, Peña ET, González JG, Pozo JG, } \\
\text { Vasco IG, Rodríguez BP. }{ }^{31}\end{array}$ & Spain & Collective health \\
\hline Marilaf MC, Alarcón AM, Illesca MP. ${ }^{32}$ & Chile & Collective health \\
\hline $\begin{array}{l}\text { Jiménez-García Á, Granados-Bolívar ME, } \\
\text { Fernández-Moreno C. }{ }^{33}\end{array}$ & Spain & Collective health \\
\hline Sivamalai $S .{ }^{34}$ & Australia & Collective health \\
\hline Rolland RA. ${ }^{35}$ & USA & Collective health \\
\hline $\begin{array}{l}\text { Pimmer C, Brysiewicz P, Linxen S, Walters F, } \\
\text { Chipps J, Gröhbiel U. }{ }^{36}\end{array}$ & $\begin{array}{l}\text { South Africa and } \\
\text { Switzerland }\end{array}$ & telehealth \\
\hline Carter-Templeton HD, Wu L. ${ }^{37}$ & USA & telehealth \\
\hline
\end{tabular}

Next, the themes addressed in the articles will be presented: training and continuing education, collective health, hospital care, job satisfaction, telehealth, regulation central and recruitment.

\section{Training and Permanent education}

Of the 30 articles in this review, ten ${ }^{14-23}$ dealt specifically with rural nursing training and one with continuing education. ${ }^{13}$ These studies have addressed different aspects regarding education in rural nursing, which comprise curricular internships in rural health services; and semi-distance professional qualification courses. The data showed that these activities aim to improve the access of students from rural areas; to encourage schools to assume the responsibility of training properly qualified nurses to meet the needs of their geographical region, with the use of culturally accepted resources; to offer internships in rural areas to undergraduate students, as well as continuing education and professional development programs.

\section{Collective health}

The studies ${ }^{28-35}$ identified that the activities developed by rural nursing range from the care function, such as a home visit, nursing consultation and management activities; to educational activities, such as activities with community groups. For this, the professional needs to have specialized skills and competences on the health inequalities experienced by communities; rural bioethics; political awareness; creativity and assertive communication.

\section{Hospital care}

The studies ${ }^{9-12}$ address the nursing practice in small rural hospitals, in which they play an important role in local, regional and national health services, developing curative, preventive, urgency and emergency actions. According to the country's health legislation, these professionals can perform procedures such as childbirth and minor surgeries.

\section{Job satisfaction}

The data ${ }^{25-27}$ reveal that the rural lifestyle was pointed out as the reason for the professionals to choose to work in these areas, although this choice limits the practice and professional qualification. Regardless of their age, years of experience and educational background, the participants report being satisfied with their work and wages. 


\section{Telehealth}

This topic was discussed in two studies, ${ }^{36-37}$ both assessed the use of online resources for clinical decision making. They identified that access to information allowed for the construction and exchange of knowledge and emotional support, contributing to the work and care process. It is a tool that can offer the professionals working in rural areas training and continuing education activities, as well as promote the performance of quality activities in due time. However, the use of technology not only results in positive effects, it also brings a series of ethical issues such as conducting online consultations, telediagnosis and administration of medications, as well as performing procedures prescribed by remotely consulted physicians. These challenges concern the professional development, the adoption of safe practices and the protection of the privacy of the new spaces. ${ }^{36-37}$

\section{Regulation Central}

A study ${ }^{8}$ sought to know the actions developed in five Urgency and Emergency Regulation Centrals and the factors that influence their performance. It identified that the nurse provides agile and efficient care, using the clinical knowledge she has on the population to determine the necessary intervention. The study concluded that including this service in the rural area offers a unique care to the population, which benefits from the professional experience in the rural territory and from the knowledge about the particularities of the population served for decision-making.

\section{Recruitment}

A study conducted in Canada ${ }^{24}$ that aimed to discuss the recruitment policy and the permanence of nurses in rural areas identified that several aspects influence these issues, among which the following stand out: scarcity of labor; lack of infrastructure in health organizations and lack of interest for rural health by the representatives of the public authorities.

\section{DISCUSSION}

Regarding the aspects that influence the practice of rural nursing, social, geographic or professional isolation stands out, ${ }^{20,24,28-29}$ which requires the development of an independent practice, with little or no assistance from other professionals, and also with the performance of independent functions in primary health management, treating simple and complex signs and symptoms in various practice sites, such as basic health units, hospitals, clinics, geriatric homes, the urgency regulation central and telehealth.

A study conducted in the USA shows that nurses provide care to people living in rural or remote areas, who often do not have health insurance or access to other services. Their actions emphasize health promotion, disease prevention and primary care provision, constituting a significant activity in solving the health care crisis in rural communities. ${ }^{38}$

Isolation, associated with the need to make independent decisions ${ }^{24}$ creates a territory of clinical risk that demands more from the professional, and it is necessary to unite the clinical knowledge and that about the particularities of each population to meet the care needs. This allows acting in the face of a critical event, a moment when knowing the rural experience and understanding the population's behavior becomes an important factor for decision-making. ${ }^{28}$

These scenarios highlight the need to bring the clinical practice of nursing closer to reflective thinking applied to action, which seeks to act on the practice, and postulates the adaptation of theories, methods, and techniques that allow for a fluid communication and for the participation of care-involved individuals. ${ }^{39}$ 
Isolation also comprises the distance from other health services, which also influences rural practice, since the professionals rarely have the opportunity to exchange experiences and, in most cases, are unaware of the rural nursing practices produced in other services and countries. ${ }^{20}$ Added to this is the fact that you have to deal with limited resources, ${ }^{8}$ with the lack of labor ${ }^{20,24}$ and with the precarious infrastructure of health organizations. ${ }^{24}$

It was identified that these professionals have unique experiences in different territories, caring for individuals who have unique health profiles, ${ }^{20}$ often needing to care for people with whom they have emotional ties such as friends, neighbors and even family members. ${ }^{29-30}$ Thus, the concrete actions in rural nursing become a practice committed to solving problems in each of the different scenarios, which enables the exercise of critical reflection on the actions taken and the construction of different care possibilities.

In this territory, knowing the community helps in the development of a creative and responsive sense ${ }^{20}$ the longer the time of the acting permanence in the same community, the easier it will be to manage situations of risk and stress. ${ }^{9,28}$ However, this bond may encourage the development of feelings of obligation towards the community, ${ }^{20}$ which may lead to actions that run away from assistance, ${ }^{30}$ making the concrete actions in rural nursing a unique way to care in each territory.

As an important competence in rural areas, the studies also point out knowing the culture of the users so as to offer relevant care with self-care performed by the family and the community. ${ }^{32}$ The socio-anthropological and cultural character of nursing, which has the human being as its object of work and study, was recognized in these care territories, which meet different life cycles, in a healthdisease situation, aiming to offer a holistic care, which overcomes fragmentation, contemplating habits, culture and mechanism of needs' satisfaction and health education. ${ }^{40}$

Living and working in rural communities requires learning and exercising different ways of being in practice and in relation. Privacy, confidentiality, and work-life balance are some of the challenges faced. ${ }^{20}$ In small communities, the limits of the nurse's role and the social being balance may have a thin line difficult to visualize, with their own rules that aim at building and maintaining a good relationship with families. ${ }^{30}$

These relationships do not necessarily start with the nursing consultation, the performance of a procedure or home visit; nor do they end in themselves, they just change. All this requires skills such as courage, daring, creativity, innovation, tenacity, communication and a good understanding of oneself. ${ }^{9}$ The nurse who works in rural areas, besides dealing with relationships that go beyond caring, has to continuously overcome the strong history of oppression, to ensure that the nursing practice is recognized in a society where the hospital medical practice, the gender imbalance and unequal power relations predominate, which may be more present and evident in rural areas than in urban ones. ${ }^{41}$

In accordance, a study points out that few professions have experienced so many struggles throughout their history, and that nursing is inevitably linked to the female gender; so, to speak of female identity and nurse identity is to speak of the same history. Gender oppression oppresses nursing; the difficulties of rural women to be heard, to have their work recognized, not only as help, reflects directly on the difficulty of the rural nurse to be recognized as a health professional who provides essential care to individuals, families and the community. ${ }^{42}$

For the rural nurse, community life continues after the care is provided, unlike what happens among the professionals who work in urban communities or hospitals. In rural areas, what changes are the ways of relating, the needs, territories, and circumstances. ${ }^{14,22}$ The nurse sometimes cares for, sometimes she is the client who buys the products produced in the community, sometimes she is the mother of a school pupil.

As an example of this continuous life, a study ${ }^{30}$ uses a grocery store as a reference, as a metaphor for a common denominator of humanity to the caregiver and the one being cared for, the 
basic need to eat, live, coexist, support and raise a family. The ephemeral nature of the human existence daily life, which reminds us that no one can escape the human condition: tragedy, beauty, contradiction, and complexity of living. Some studies ${ }^{20,28}$ recognize that no matter how enthusiastic about the profession rural nurses may be, they face barriers such as isolation, the inflexibility of workload, limited resources, and lack of financial support and time. In rural areas, the lack of employees makes the work more stressful. Labor shortages are a problem in rural and urban areas but, in the former, it is more likely that overtime will be required due to the lack of alternative assistance to the nearby population.

Data analysis revealed that one of the greatest challenges in the long- and medium-term is to train nurses who perform quality care, respecting the specificities of rural communities, in the geographic areas where they are needed.

Based on the discussion, we consider that rural nursing has specificities that go beyond the general clinical practice; encompass the ability to deal with problems; act on the community's behalf; offer intentional support; know the local culture and act as an educator..$^{9,17,33}$ In order to provide a quality service, they must have independence and self-direction, develop critical thinking and have a solid foundation in the art and science of nursing, ${ }^{28}$ coming from the biomedical system and other care systems.

Thus, the importance of permanent qualification is revealed, aiming at the development of practical skills in the exercise of daily actions. A study from Australia, ${ }^{34}$ identified that in rural areas, due to local and population specificities, nurses need to be able to perform health education activities. For, although modernity offers health information, these professionals continue to be an important support for communities, which often lack technological resources. This attribution stands out mainly in less developed regions, as is the case of the Brazilian rural communities, which in addition to not having the technological resources, have an elderly rural population with few years of study, due to the historical deficit of formal education in rural areas. ${ }^{43}$

In the meantime, the nurse works in partnership with the individuals, recognizing and supporting their capabilities, giving them opportunities to express themselves, and for having specialized knowledge about the health inequalities experienced by communities, which are often isolated, she uses her work to try to minimize these inequalities through emancipatory actions called accountability. ${ }^{12}$

These professionals, on many occasions, act on behalf of the community and, on others, offer intentional support, encouragement, acting as an educator, promoting healthy and positive human relationships, even when individuals are not yet ready to make a change in daily life. ${ }^{13}$ The professional becomes a member of the community, concerned with all that directly or indirectly affects it, and not just support in cases related to the health-disease process.

In the rural nursing practice, the dialog with other areas such as sociology, philosophy, anthropology, and education is of great importance due to the socio-political and educational component of the nurse's work. In the studies that made up this review, the dialog with anthropology was presented by recognizing the need to know the cultural specificities of each location and the health resources used in these territories. ${ }^{12,28,32}$

A study conducted in Spain showed that, in the rural setting, nurses consider it an important competence to know the culture of the subjects, and to use it as a basis for the provision of care relevant to the practices developed by families and communities. This concept of cultural care emerged as a fundamental pillar of the rural nursing specificities. ${ }^{32}$

These professionals understand that, without knowing what it means to care for the rural population, there is no way to perform the main nursing functions (care, education, and administration), because they will not meet their care needs. Therefore, for rural nursing, it is especially important 
that the professional devote more time to contact the community, demanding care of excellence in content and quality. ${ }^{32}$

Considering these specificities found in the practice of rural nursing, the need is highlighted to direct a sensitive look at the rural population, which is inserted in a specific social, political, historical, economic and cultural territory. This data is in line with the study ${ }^{44}$ conducted with nurses, which points out that this being, thinking and acting professionally requires the construction of values and ways to understand the world and the subjects, aiming at their autonomy in their care. In the case of rural communities, it may be family or community.

The study ${ }^{44}$ also points out the need to approach knowledge in a perspective of respect and understanding of the beliefs and values of the community. Reinforcing the socio-critical theory contributions to broaden our view on the human being, resulting from the training influenced by the biomedical system, which directs vertical and decontextualized practices.

In the rural perspective, the understanding of the beliefs and values can be extended to the family and even to the individuals, due to the complex arrangements found in each family, considering that these values are attributed to the interaction with the environment, animals and plants. These territories are living laboratories which, in the historical territory, knowledge valued by the different cultural groups that compose them are accumulated. The nurse, in the presented territory, plays the role of an observer and communicator, which implies the development of a relationship of help, care, affection, and growth.

As the study's limits, it is noted that the articles that came from Brazil explored the perspective of population health and research on family care or self-care, not emphasizing the nursing practice and, therefore, did not fit the inclusion criteria.

\section{CONCLUSION}

The challenges of providing a qualified nursing care, in a timely and humanized manner, to individuals, families and communities living in rural areas are complex, in tune with the contemporary ways of life.

These topics addressed the rural nursing training from undergraduate up to the offering of specific graduate courses for rural action; continuing education activities; nurse's performance in collective health, hospital care, telehealth services and the urgency and emergency regulation central. Apart from addressing job satisfaction and the system for recruiting professionals to work in rural areas, revealing a diversity of actions developed in the rural territory.

The performance of these actions demands facing particularities such as isolation, difficulty of access, diverse socioeconomic conditions and specific epidemiological profiles that influence the professional practice, which makes this experience creative and unique.

These challenges begin with undergraduation, period during which, because a generalist formation is advocated, most of the time they end up not providing the care experience in the rural territory. The importance is highlighted of bringing nursing knowledge closer to other areas such as sociology, anthropology, and agricultural sciences, areas which can contribute to the development of quality and meaningful care, given the countless specificities listed.

It is understood that the challenges for the future of rural nursing is to promote a broad agreement as a public policy within each nation, to induce a critical education that meets the various challenges to overcome the weaknesses of the health-disease process. The training of nurses should be sensitive to the rural territory contemplating the specificities and needs, if any, including in their pedagogical project the importance of critical and emancipatory training, under the specificities found, contributing to the quality of life and health of the rural population in all life cycles. 


\section{REFERENCES}

1. International Labour Organization. Global evidence on inequities in rural health protection: New data on rural deficits in health coverage for 174 countries. Geneva: International Labour Office; 2015.

2. Schwartz E, Elsen I, Zillmer JGV, Santos BZ, Lise F. A vulnerabilidade das famílias rurais do extremo sul do Brasil. Investigação Qualitativa em Saúde [Internet]. 2016 [cited 2018 Jul 17];2:722-7. Available from: https://proceedings.ciaiq.org/index.php/ciaiq2016/article/view/816

3. Heck RM, editor. Plantas medicinais do Bioma Pampa no cuidado em saúde. Brasília, DF(BR): Embrapa; 2017.

4. Viero CM, Camponogara S, Cezar-Vaz MR, Costa VZ, Beck CLC. Sociedade de risco: o uso dos agrotóxicos e implicações na saúde do trabalhador rural. Esc Anna Nery [Internet]. 2016 [cited 2018 Jul 17];20(1):99-105. Available from: http://dx.doi.org/10.5935/1414-8145.20160014

5. Budó MLD, Saupe R. Modos de cuidar em comunidades rurais: a cultura permeando o cuidado de enfermagem. Texto Contexto Enferm [Internet]. 2005 [cited 2018 Jul 17];14(2):177-85. Available from: http://dx.doi.org/10.1590/S0104-07072005000200004

6. Mendes, KDS, Silveira, RCCP, Galvão CM. Revisão integrativa: método de pesquisa para a incorporação de evidências na saúde e na enfermagem. Texto Contexto Enferm [Internet]. 2008 [cited 2018 Aug 07];17(4):758-64. Available from: http://www.scielo.br/pdf/tce/v17n4/18.pdf

7. Minayo MCS. Análise qualitativa: teoria, passos e fidedignidade. Ciênc Saúde Colet [Internet]. 2012 [cited 2018 Aug 10];17(3):621-6. Available from: http://dx.doi.org/10.1590/S010407072008000400018

8. Knight K, Kenny A. Assessing clinical urgency via telephone in rural Australia. Nurs Health Sci [Internet]. 2015 [cited 2018 Jul 13];17(2):201-7. Available from: https://dx.doi.org/10.1111/nhs.12161

9. Bish M, Kenny A, Nay R. Using participatory action research to foster nurse leadership in Australian rural hospitals. Nurs Health Sci [Internet]. 2013 [cited 2018 Jul 15];15(3):286-91. Available from: https://dx.doi.org/10.1111/nhs.12030

10. Beckstrand RL, Rohwer J, Luthy KE, Macintosh JLB, Rasmussen RJ. Rural emergency nurses' end-of-life care obstacle experiences: stories from the last frontier. J Emerg Nurs [Internet]. 2017 [cited $2018 \mathrm{Jul}$ 15];43(1):40-48. Available from: https://dx.doi.org/10.1016/j.jen.2015.08.017

11. Kenny A, Allenby A. Implementing clinical supervision for Australian rural nurses. Nurse Educ Pract [Internet]. 2013;13(3):165-9. Available from: https://dx.doi.org/10.1016/j.nepr.2012.08.009

12. Beckstrand RL, Giles VC, Luthy KL, Callister PLC, Heaston S. The last frontier: rural emergency nurses' perceptions of end-of-life care obstacles. J Emerg Nurs [Internet]. 2012 [cited 2018 Jul 15];38(5):e15-25. Available from: https://dx.doi.org/10.1016/j.jen.2012.01.003

13. Fairchild MR, Everly M, Bozarth L, Bauer R, Walters L, Sample M, et al. A qualitative study of continuing education needs of rural nursing unit staff: The nurse administrator's perspective. Nurse Educ Today [Internet]. 2013 [cited 2018 Jul 14];33(4):364-9. Available from: https://dx.doi. org/10.1016/j.nedt.2012.05.023

14. Lea J, Cruickshank M. Supporting new graduate nurses making the transition to rural nursing practice: views from experienced rural nurses. J Clin Nurs [Internet]. 2015 [cited 2018 Jul 12];24(19-20):2826-34. Available from: https://dx.doi.org/10.1111/jocn.12890

15. Hauenstein EJ, Glick DF, Kane C, Kulbok P, Barbero E, Cox K. A model to develop nurse leaders for rural practice. J Prof Nurs [Internet]. 2014 [cited 2018 Jul 9];30(6):463-73. Available from: https://dx.doi.org/10.1016/j.profnurs.2014.04.001 
16. Tschetter L, Lubeck P, Fahrenwald N. Integrating QSEN and Technology to Address Rural Health Care: Initial Outcomes. Clin Simul Nurs [Internet]. 2013 [cited 2018 Jul 3];9(10):469-75. Available from: https://dx.doi.org/10.1016/j.ecns.2012.09.005

17. Pront $L$, Kelton M, Munt R, Hutton A. Living and learning in a rural environment: A nursing student perspective. Nurse Educ Today [Internet]. 2013 [cited 2018 Jul 4];33(3):281-5. Available from: https://dx.doi.org/10.1016/j.nedt.2012.05.026

18. Yonge OJ, Myrick F, Ferguson LM, Grundy Q. Nursing preceptorship experiences in rural settings: "I would work here for free". Nurse Educ Pract [Internet]. 2013 [cited 2018 Jul 4];13(2):125-31. Available from: https://dx.doi.org/10.1016/j.nepr.2012.08.001

19. Sanderson H, Lea J. Implementation of the Clinical Facilitation model within an Australian rural setting: The role of the Clinical Facilitator. Nurse Educ Pract [Internet]. 2012 [cited 2018 Jul 4]; 12(6):333-339. Available from: https://dx.doi.org/10.1016/j.nepr.2012.04.001

20. Place J, MacLeod M, John N, Adamack M, Lindsey AE. "Finding my own time": Examining the spatially produced experiences of rural RNs in the rural nursing certificate program. Nurse Educ Today [Internet]. 2012 Jul [cited 2018 Jul 4];32(5):581-7. Available from: https://dx.doi. org/10.1016/j.nedt.2011.07.004

21. Sedgwick MG, Yonge O. Undergraduate nursing students' preparedness to "go rural". Nurse Educ Today [Internet]. 2008 [cited 2018 Jul 17];28(5):620-6. Available from: https://dx.doi. org/10.1016/j.nedt.2007.09.014

22. Mills J, Francis K, Bonner A. Getting to know a stranger-rural nurses' experiences of mentoring: A grounded theory. Int J Nurs Stud [Internet]. 2008 [cited 2018 Jul 5];45(4):599-607. Available from: https://dx.doi.org/10.1016/j.ijnurstu.2006.12.003

23. Latham H, Giffard L, Pollard M. University and Health Service Partnership: A Model to Deliver Undergraduate Nurse Education in Rural Australia. Collegian [Internet]. 2007 [cited 2018 Jul 6];14(1):5-10. Available from: https://dx.doi.org/10.1016/S1322-7696(08)60541-7

24. Kulig JC, Kilpatrick K, Moffitt P, Zimmer L. Recruitment and retention in rural nursing: it's still an issue! Nurs Leadersh (Tor Ont) [Internet]. 2015 [cited 2018 Jul 6];28(2):40-50. Available from: https://dx.doi.org/10.12927/cjnl.2015.24353

25. Yates $\mathrm{K}$, Kelly J, Lindsay D, Usher $\mathrm{K}$. The experience of rural midwives in dual roles as nurse and midwife: "l'd prefer midwifery, but I chose to live here". Women Birth [Internet]. 2013[cited $2018 \mathrm{Jul}$ 17];26(1):60-4. Available from: https://dx.doi.org/10.1016/j.wombi.2012.03.003

26. Terri Bolin T, Peck D, Moore C, Ward-Smith P. Competency and educational requirements: perspective of the rural emergency nurse. J Emerg Nurs [Internet]. 2011 [cited 2018 Jul 9];37(1):969. Available from: https://dx.doi.org/10.1016/j.jen.2010.06.022

27. Hoodless M, Bourke L. Expanding the scope of practice for enrolled nurses working in an Australian rural health service: Implications for job satisfaction. Nurse Educ Today [Internet]. 2009 [cited 2018 Jul 9];29(4):432-8. Available from: https://dx.doi.org/10.1016/j.jen.2010.06.022

28. Knight K, Kenny A, Endacott R. From expert generalists to ambiguity masters: using ambiguity tolerance theory to redefine the practice of rural nurses. J Clin Nurs [Internet]. 2016 [cited 2018 Jul 7];25(11-12):1757-65. Available from: https://dx.doi.org/10.1111/jocn.13196

29. MacKinnon K, Moffitt P. Informed Advocacy Rural, Remote, and Northern Nursing Praxis. ANS Adv Nurs Sci [Internet]. 2014 [cited 2018 Jul 7];37(2):161-73. Available from: https://dx.doi. org/10.1097/ans.0000000000000025

30. Moules NJ, MacLeod MLP, Thirsk LM, Hanlon N. "And Then You'll See Her in the Grocery Store": The Working Relationships of Public Health Nurses and High-Priority Families in Northern Canadian Communities. J Pediatr Nurs [Internet]. 2010 [cited 2018 Jul 11];25(5):327-34. Available from: https://dx.doi.org/10.1016/j.pedn.2008.12.003 
31. Fraile MB, Peña ET, González JG, Pozo JG, Vasco IG, Rodríguez BP. Las cencerradas: una visión antropológica desde la enfermería rural. Temperamentvm [Internet]. 2006 [cited 2018 Jul 10];3. Available from: http://www.index-f.com/temperamentum/tn3/t0130r.php

32. Marilaf MC, Alarcón AM, Illesca MP. Rol del enfermero/a rural en la región de la Araucanía Chile: percepción de usuarios y enfermeros. Cien Enfermería [Internet]. 2011 [cited 2018 Jul 10];17(2):111-8. Available from: https://dx.doi.org/10.4067/S0717-95532011000200012

33. Jiménez-García Á, Granados-Bolívar ME, Fernández-Moreno C. Vivencias de una enfermera en su primera experiencia como profesional de los cuidados en entorno rural. Arch Memoria [Internet]. 2015 [cited 2018 Jul 17];12(2). Available from: http://www.index-f.com/memoria/12/12206r.php

34. Sivamalai S. Desired attributes of new graduate nurses as identified by the rural community. Rural Remote Health [Internet]. 2008 [cited 2018 Jul 30];8:938. Available from: https://www.rrh. org.au/journal/article/938.

35. Roland RA. Emergency Room Nurses Transitioning from Curative to End-of-Life Care: The Rural Influence. Online J Rural Nurs Health Care [Internet]. 2016 [cited 2018 Jul 3];16(2):58-85. Available from: https://dx.doi.org/10.14574/ojrnhc.v16i2.396

36. Pimmer C, Brysiewicz P, Linxen S, Walters F, Chipps J, Gröhbiel U. Informal mobile learning in nurse education and practice in remote areas: A case study from rural South Africa. Nurse Educ Today [Internet]. 2014 [cited 2018 Jul 17];34(11):1398-404. Available from: https://dx.doi. org/10.1016/j.nedt.2014.03.013

37. Carter-Templeton HD, Wu L. Using Mobile Technologies to Access Evidence-Based Resources: A Rural Health Clinic Experience. Nurs Clin N Am [Internet]. 2015 [cited 2018 Jul 2];50:595-03. Available from: https://dx.doi.org/10.1016/j.cnur.2015.05.012

38. Brown J, Hart AM, Burman ME. A day in the life of rural advanced practice nurses. J Nurse Pract [Internet]. 2009 [cited 2018 Jul 1];5(2):108-14. Available from: https://dx.doi.org/10.1016/j. nurpra.2008.10.013

39. Ceolin S, Piriz MA, Mendieta MC, Siles Gonzalez J, Heck RM. Elements of the socio-critical paradigm in nursing care practices: an integrative review. Rev Esc Enferm USP [Internet]. 2017 [cited 2018 Jul 17];51:e03267. Available from: https://dx.doi.org/10.1590/s1980-220x2016037003267

40. Siles GJ, Solano RMC. A história cultural e a estética dos cuidados de enfermagem. Rev LatinoAm Enfermagem [Internet]. 2011 [cited 2018 Aug 17];19(5):1096-1105. Available from: https:// dx.doi.org/10.1590/S0104-11692011000500006

41. Hauenstein EJ, Glick DF, Kane C, Kulbok P, Barbero E, Cox K. A Model to Develop Advanced Practice Nurses for Rural Settings. J Prof Nurs [Internet]. 2014 [cited 2018 Aug 17];30(6):46373. Available from: https://dx.doi.org/10.1016/j.profnurs.2014.04.001

42. Mínguez I, Siles J. Crisis de identidad enfermera: Origen y... ¿ superación a través de la práctica reflexiva en el entorno comunitario? Ridec [Internet]. 2010 [cited 2018 Aug 17];3(2):5-8. Available from: https://www.researchgate.net/publication/234046188_crisis_de_identidad_enfermera_ origen_y_superacion_a_traves_de_la_practica_reflexiva_en_el_entornocomunitario.

43. Soares NA, Morgan BS, Santos FBO, Matozinhos FP, Penna MM. Crenças e práticas de saúde no cotidiano de usuários da rede básica de saúde. Rev Enferm UERJ [Internet]. 2014 [cited 2018 Aug 17];2(1):83-8. Available from: https://www.e-publicacoes.uerj.br/index.php/enfermagemuerj/ article/view/11450

44. Ceolin S, Gonzales JS, Ruiz MCS, Heck RM. Theoretical bases of critical thinking in IberoAmerican nursing: integrative literature review. Texto Context Enferm [Internet]. 2017 [cited 2018 Aug 17];26(4):e3830016. Available from: https://dx.doi.org/10.1590/0104-07072017003830016 


\section{NOTES}

\section{ORIGIN OF THE ARTICLE}

Extracted from the thesis - Care Possibilities in Rural Nursing: Approaches from the Socio-critical Theory, presented to the Nursing Post-graduation Program of the Universidade Federal de Pelotas, in 2018.

\section{CONTRIBUTION OF AUTHORSHIP}

Study Desing: Lima ARA, Heck RM.

Data collection: Lima ARA.

Analysis and interpretation of data: Lima ARA, Heck RM.

Discussion of the results: González JS, Ruiz MCS, Lima ARA, Heck RM.

Writing and/or critical review of content: González JS, Ruiz MCS, Heck RM.

Review and final approval of the final version: Heck RM.

\section{ACKNOWLEDGMENT}

To the Rural Nursing and Sustainability Research group of the Universidade Federal de Pelotas.

\section{CONFLICT OF INTERESTS}

There is no conflict of interest.

\section{HISTORICAL}

Received: November 20, 2018.

Approved: April 17, 2019.

\section{CORRESPONDING AUTHOR}

Ângela Roberta Alves Lima

angelarobertalima@hotmail.com 